\title{
Phonology Processing and Reading Ability in Elementary School-aged children with Cleft Palate
}

\author{
Yu Gyeong Choe ${ }^{a}$, Seunghee $\mathrm{Ha}^{\mathrm{b}}$ \\ ${ }^{a}$ Graduate Program in Speech Language Pathology, Hallym University, Chuncheon, Korea \\ ${ }^{b}$ Division of Speech Pathology and Audiology, Audiology and Speech Pathology Research Institute, Hallym University, Chuncheon, Korea
}

\author{
Correspondence: Seunghee $\mathrm{Ha}, \mathrm{PhD}$ \\ Division of Speech Pathology and Audiology, \\ Audiology and Speech Pathology Research \\ Institute, Hallym University, 1 Hallymdaehak-gil, \\ Chuncheon 24252, Korea \\ Tel: $+82-33-248-2215$ \\ Fax: +82-33-256-3420 \\ E-mail: shha@hallym.ac.kr
}

Received: July 5, 2021

Revised: August 4, 2021

Accepted: August 15, 2021
Objectives: This study aimed to examine the phonological processing and reading abilities of elementary school-aged children with and without cleft palate (CP). Methods: The participants were 10 children with $\mathrm{CP}$ and 12 typically developing children in the first to the second grades of elementary school. All children with CP in the study were identified with speech and language development problems during preschool age and were recommended speech and language therapy. The performances of phonological processing were measured in terms of phonological awareness (syllable and phoneme awareness), phonological memory (nonword repetition, digit span and backward digit span), and rapid automatized naming. The reading abilities were also measured in terms of decoding, reading fluency and reading comprehension. The correlations among vocabulary, articulation, and phonological processing and reading ability were examined. Results: Children with CP showed significantly lower performances in phonological awareness of syllable level and nonword repetition than typically developing children. Also, significant group differences were seen in all decoding and reading comprehension tasks except reading fluency. The results showed that nonword repetition performances of children with CP were highly correlated with receptive vocabulary and percentage of consonants correct. Conclusion: This study confirmed that school-aged children with CP who showed speech sound disorders in preschool age are likely to have difficulties in phonological processing and reading. Therefore, this study suggested that comprehensive evaluation of phonological processing skills should be performed more actively in preschool children with $\mathrm{CP}$ who show speech sound disorders, and intervention should continue to improve reading skills for school age.

Keywords: Phonological processing, Reading abilities, Cleft palate, Elementary school
구개열 아동은 선천적으로 조음기관 구조에서 결함을 보여 제한 적인 자음목록 수, 단순한 음운구조를 보이며 초기 음운발달부터 지연을 보인다(Chapman, 1991). 이후 구개 수술을 통해 조음기관 구조가 회복되어도 구강기제 대신 성대 또는 인두를 사용하여 발 음하는 보상조음 오류를 보이며 구강 자음 산출에서 지속적인 어 려움을 보일 가능성이 높다(Chapman, 1993; Ha, 2019; Ha, Jung, Koh, \& Oh, 2018; Hardin-Jones \& Jones, 2005; Pi \& Ha, 2017; Scherer \& D’antonio, 1995). 3-6세 구개열 아동 집단과 기능적 조음장애 아동 집단과 일반 아동 집단 간 자음정확도, 말명료도, 말용인도를 비교한 Han과 Shim (2008)은 구개열 아동이 모든 능력에서 일반
아동보다 유의하게 낮게 나타났다고 보고하였다. 또한 다수의 선행 연구에서 구개열 아동이 영유아 시기까지 수용언어 발달에서 지연 을 보이다가 이후에는 일반 아동과 유사한 수행력을 보이지만, 표현 언어 능력에서는 여전히 구개열 아동이 지연을 보일 가능성이 크다 고 제시하였다(Broen, Devers, Doyle, Prouty, \& Moller, 1998; Chapman, Graham, Gooch, \& Visconti, 1998; Collett, Leroux, \& Speltz, 2010). Eliason과 Richman (1990)은 4-6세 구개열 아동의 언어 및 기억력 발달을 살펴보았는데, 구개열 아동은 평균 수준의 어휘 정 의, 언어적 유사성 및 기억력을 보였으나, 그림 범주화와 시·감각 기 억력에서는 유의하게 낮은 수행력을 보였다. 그리고 Eliason과 Rich- 
$\operatorname{man}$ (1990)은 구개열 아동이 전반적인 언어 지연보다는 시연(rehearsal)과 이름대기(verbal labeling)와 같은 전략을 사용하는 데 제한을 보이면서 특정 영역의 언어 능력에서 어려움을 보인다고 제 시하였다. 구개열 아동의 말-언어 발달을 영유아기에서부터 학령전 기, 학령기까지 살펴본 Kuehn과 Moller (2000)는 구개열 아동이 학 령기, 성인까지 말과 언어 발달 문제가 지속될 가능성이 높으므로 주기적인 평가가 중요함을 제안하고 있다.

한편, 많은 선행연구에서 학령전기에 말소리장애를 보였던 아동 중 음운처리 과정에서의 결함으로 인해 말소리 산출 상의 문제를 보였던 아동은 이후 학령기에서 읽기 상의 어려움을 보일 위험이 크다고 보고하였다(Bird, Bishop, \& Freeman, 1995; Bishop \& Adams, 1990; Larrivee \& Catts, 1999; Rvachew, Ohberg, Grawburg, \& Heyding, 2003). 4-5세에 말소리장애만 보였던 아동 집단과 말과 언어장애를 함께 보였던 아동 집단을 추적 조사하여 6세의 읽기와 철자 능력을 살펴본 Nathan, Stackhouse, Goulandris와 Snowling (2004)은 말과 언어장애를 함께 보였던 집단이 읽기와 철자 능력에 서 지연된 발달을 보였다고 제시하였다. 그리고 Bird 등(1995)은 학령 기까지 심각한 표현 음운 장애를 계속 보일 경우 언어장애 동반 여 부와 상관없이 읽기 및 쓰기에서 문제를 보일 위험이 크다고 제시 하였다. Lee 등(2018)은 4-6세 말소리장애 아동을 음운인식 능력에 따라 언어 능력과 음운처리 능력을 살펴보았다. 그 결과, 음운인식 능력이 낮은 말소리장애 아동이 무의미 낱말 따라말하기, 빠른 이 름대기, 표현 어휘력에서 유의하게 낮은 수행력을 보였다. 연구자들 은 연구결과를 통해 말소리장애 아동이 낮은 음운인식 능력을 보 일 경우 이후 문해 능력에서도 결함을 보일 위험이 크다고 제안하 였다. 따라서 말과 언어장애가 지속될 경우 이후 학령기에 읽기 상 의 문제를 보일 위험이 크므로, 조기에 말과 언어 문제를 중재해야 하며, 나아가 적절한 읽기 발달을 위한 음소 지식을 습득시키는 중 재가 이루어져야 한다(Nathan et al., 2004). 학령기 아동들에게 읽 기 능력은 성공적인 학습을 위해 중요하다. 특히 음운인식, 음운기 억, 빠른 이름대기, 단기기억, 작업기억 등의 음운처리 능력은 읽기 능력을 예측하는 요인이다(Ackerman \& Dykman, 1993; Cormier \& Dea, 1997; Siegel, 1993). 따라서 학령전기 음운인식 및 처리 능력 에서 어려움을 보인다면 학령기 읽기 능력에서 문제를 보일 위험이 높으므로 보다 적극적인 평가와 중재가 필요하다(Bird et al., 1995; Bradley \& Bryant, 1983).

말소리장애와 음운처리 및 읽기 장애와의 긴밀한 관계를 구개열 아동에게 적용한다면 구개열 아동은 보상조음과 같은 말 문제를 빈번하게 보이기 때문에 학령기에 음운처리와 읽기 상의 어려움을 보일 가능성이 훨씬 높다고 추론해볼 수 있다. 실제로 Richman과
Eliason (1984)의 연구에서는 6-7세 구순구개열과 구개열 아동이 각각 $49 \%$ 와 $53 \%$ 의 읽기장애 발생률을 보여 일반 아동보다 읽기 상 의 어려움을 보일 가능성이 높게 나타났다. 또한 9,10 세 구개열 아 동의 읽기장애 출현율을 살펴본 Weinfeld, Johnels과 Persson (2021) 의 연구에서는 구개열 아동 집단의 $22 \%$ 가 난독형 읽기장애를 가질 위험을 보였고, 주의력, 언어, 학습 능력에서 문제를 동반한 경우에 는 읽기장애를 가질 위험이 더욱 높아졌다.

구개열 아동을 대상으로 읽기 능력과 함께 음운처리 등 관련 요 인과의 관계도 살펴본 연구도 다수 있다. Alighier 등(2020)은 7-12 세 구개열 아동의 읽기 및 쓰기 능력과 언어 처리 간의 관계를 살펴 보았다. 연구결과, 읽기 능력과 음운인식 간의 유의한 상관이 있었 고, 쓰기 능력과 작업기억 간에도 유의한 상관이 있었다고 제시하 였다. 그리고 다수의 선행연구에서는 구개열 아동의 언어와 읽기 능력에 영향을 미치는 요인으로 읽기와 관련된 신경심리학적 능력 인 음운인식, 빠른 이름대기, 청각적 또는 시각적 기억력에서의 결 함을 제시하였다(Ceponiene, Haapanen, Ranta, Naatanen, \& Hukki, 2002; Richman \& Ryan, 2003; Richman, Wilgenbusch, \& Hall, 2005). Conrad, McCoy, DeVolder, Richman과 Nopoulos (2014)은 7-26세 구개열 집단의 말, 청력, 신경심리학적 능력 간의 상관관계 를 살펴본 결과, 구개열 집단은 단어 읽기 검사에서 일반 집단보다 유의하게 저조한 수행력을 보였다고 제시하였다. 또한, 구개열 집단 의 경우 단어 읽기 결함이 말이나 청력보다는 청각적 기억력 문제 와 상관이 있었다. Richman 등(2005)은 7-9세 구개열 아동을 대상 으로 어떠한 유형의 기억력 결함이 읽기장애와 상관이 있는지 살펴 본 결과, 시각적 기억력이 읽기 능력과 유의한 상관관계를 보였다. 읽기장애가 있는 구개열 아동과 읽기장애가 없는 구개열 아동을 대상으로 Richman과 Ryan (2003)은 구개열 아동이 발달적 난독 증 모델과 유사한 읽기장애를 보이는지 살펴보았다. 연구결과 읽기 장애가 있는 구개열 아동들은 읽기장애가 없는 구개열 아동보다 빠른 이름대기와 단어 유창성에서 유의하게 저조한 수행력을 보였 으며, 음소인식에서는 유의한 차이를 보이지 않았다. 이에 연구자 들은 구개열 아동이 발달성 난독증의 이름대기 기억력 결함 모델 과 유사한 증상을 보였으며, 빠른 이름대기가 읽기장애와 가장 중 요한 관련이 있는 요인이라고 제안하였다. 그리고 여러 선행연구에 서 구개열 아동이 기본적인 읽기 능력을 습득하여도 일반 아동보 다 음운기억 능력에서 끝까지 결함을 보인다고 제시하였다(Bishop \& Snowling, 2004; Eliason \& Richman, 1990). 한편 Bisschop (2011)은 의미와 무의미 낱말 따라말하기 과제를 이용해서 2세 구 개열 아동의 수행력을 살펴보았다. 그 결과 구개열 아동은 어휘력 과 상관없이 일반 아동 보다 의미와 무의미 낱말 따라말하기 과제 
에서 유의하게 낮은 정확도를 보였으며, 두 집단 모두 의미와 무의 미 따라말하기의 수행력 상의 유의한 차이는 나타나지 않았다. 연 구자는 연구결과를 말 산출 과정에서 음운지각상의 결함과 음운 표상과 저장 및 인출과 관련된 음운기억상의 결함과 음성 부호화 와 조음 상의 결함으로 인해 구개열 아동의 따라말하기 수행력이 떨어졌을 수 있다고 논의하였다.

대다수의 연구가 구개열 아동이 학령기에 읽기 장애를 보일 가 능성이 높다고 보고하면서 관련 요인을 연구한 반면에 구개열 아동 이 일반 아동과 유사한 읽기 능력을 보인다고 주장하는 선행연구 도 있다(Collett, Leroux et al., 2010; Collett, Stott-Miller, Cunningham, Kapp-Simon, \& Speltz, 2010). 예를 들어 3개월, 12개월, 24개 월, 5세, 7세에 거쳐 구개열 아동을 대상으로 종단 연구를 한 Collett와 Leroux 등(2010)의 연구에서는 구개열 아동이 철자 지식, 단 단어 읽기, 읽기이해력에서 오히려 일반 아동보다 높은 수행력을 보 였다. 이러한 구개열 아동의 읽기 능력에 대해 상반된 의견을 주장 하는 선행연구는 구개열 아동이 학령기에 읽기 문제를 보이는지 살 펴보는 추가적인 연구가 필요함을 시사한다. 그러나 국내에서는 학 령기 구개열 아동을 대상으로 음운처리와 읽기 능력을 살펴본 연 구는 아직까지 이루어지지 않았다. 이에 본 연구에서는 구개열 아 동을 대상으로 일반 아동과 비교하여 음운처리 능력인 음운인식, 음운기억, 빠른 자동 이름대기와 읽기 능력인 해독, 읽기 유창성, 읽 기이해에서 어떠한 수행력을 보이는지 살펴보고자 하였다. 특히 학 령전기에 말-언어 문제를 보였던 아동의 경우 학령기에 음운처리 및 읽기에 더 취약할 수 있으므로 구개열 아동을 학령전기에 말-언 어 문제를 보여 언어치료를 권고받았던 아동으로 통제하여 학령기 에 음운처리 및 읽기 상에 어떠한 특징을 보이는지 살펴보고자 하 였다. 또한, 구개열 아동 집단과 일반 아동 집단에서 어휘, 말, 음운 처리, 읽기 능력 간의 상관관계를 살펴보고자 하였다.

\section{연구방법}

\section{연구대상}

본 연구는 만 6-8세에 해당하는 초등학교 1,2학년의 구개열 아 동 10명(1학년 8명, 2학년 2명)과 일반 아동 12명(1학년 8명, 2학년 4 명)을 대상으로 이루어졌다. 집단 간 성별을 살펴보았을 때, 구개열 집단은 남아 5 명, 여아 5 명으로, 일반 집단은 남아 4 명, 여아 8 명으 로 구성되었다. 그리고 구개열 집단의 경우 파열유형에 따라 일측 구순구개열 5명, 양측 구순구개열 1 명, 구개열 4명이 참여하였다.

구개열 아동은 (1) 대학병원 구개열 클리닉에서 구개성형술을 받 았고, (2) 구개열 이외에 기타 동반 장애 및 염색체 이상으로 인한
증후군이 없고, (3) 학령전기(만 3-5세)에 말과 언어 문제를 보여 대 학병원이나 사설센터로부터 언어치료를 권고받았고, (4) 최근 6개 월 이내 중이염을 보이지 않았고, (5) 한국 비언어지능검사-제2판 (K-CTONI-2; Park, 2014)의 동작성 검사에서 지능지수가 80 이상 으로 정상범위에 속하고, (6) 주 양육자가 구강구조, 인지, 시각 및 청각과 같은 감각 상의 문제가 없다고 보고한 아동을 본 연구에 포 함하였다. 자료 수집 전에 양육자 또는 담당 언어치료사와의 면담 을 통해 파열유형, 구순 및 구개 수술 시기, 중이염 유무, 학령전기 말과 언어 문제 출현 여부 및 유형, 언어치료력 등의 사례 정보를 수 집하였다. 그 결과, 모든 구개열 아동이 학령전기에 말과 언어 문제 를 보여 대학병원 또는 사설센터로부터 언어치료를 권고받았으며, 5 명은 언어치료를 실제로 받았으며, 이 중 4 명은 자료 수집 당시에 도 언어치료를 지속적으로 받고 있었다.

일반 아동은 (1) 한국 조음음운프로파일(K-APP; Ha, Kim, Seo, $\& \mathrm{Pi}, 2021)$ 의 다양한 길이의 낱말검사 결과 자음정확도 $16 \%$ ile 이 상에 해당하고, (2) 수용 및 표현 어휘력 검사(REVT; Kim, Hong, Kim, Jang, \& Lee, 2009) 결과 수용 및 표현 어휘력이 해당 연령 평 균의 -1 표준편차 이상에 해당하고, (3) 한국 비언어지능검사-제2판 (K-CTONI-2)의 동작성 검사에서 지능지수가 80 이상으로 정상범 위에 속하고, (4) 기타 동반 장애 및 증후군이 없고, (5) 주 양육자가 구강구조, 인지, 시각 및 청각과 같은 감각 상의 문제가 없다고 보고 한 아동이었다. 두 집단의 기본정보는 Table 1 과 같다. 구개열 아동 과 일반 아동 간 생활연령, 말, 언어 능력에 유의한 차이가 있는지 살펴보기 위해 독립표본 $t$ 검정 $(t$-test $)$ 을 실시한 결과, 두 집단 간에 생활연령 $(t=1.198, p=.245)$, 수용 어휘력 $(t=-1.677, p=.109)$, 표현 어휘력 $(t=-1.983, p=.061)$, 자음정확도 $(t=-2.139, p=.061)$ 에서 모 두 유의한 차이를 보이지 않았다. 집단 간 유의한 차이는 없었지만, 구개열 아동 10 명 중 3 명이 REVT 검사 결과 수용 및 표현 어휘력에 서 $10 \%$ ile 미만으로 지연을 보였고, 이 중 2명은 K-APP 결과 자음정

Table 1. Participants' characteristics

\begin{tabular}{lcclcc}
\hline \multirow{2}{*}{ Groups } & \multicolumn{2}{c}{$\mathrm{CP}(\mathrm{N}=10)$} & & \multicolumn{2}{c}{$\mathrm{TD}(\mathrm{N}=12)$} \\
\cline { 2 - 3 } \cline { 5 - 6 } & $\mathrm{M}(\mathrm{SD})$ & Range & & $\mathrm{M}(\mathrm{SD})$ & Range \\
\hline Age (months) & $90.10(5.84)$ & $85-103$ & & $86.75(7.05)$ & $76-97$ \\
REVT_R & $83.60(25.15)$ & $31-117$ & & $97.67(13.41)$ & $66-112$ \\
REVT_E & $80.70(12.38)$ & $54-99$ & & $90.92(11.74)$ & $70-106$ \\
K-APP_PCC (\%) & $91.79(10.77)$ & $63.1-100$ & & $99.11(1.15)$ & $96.43-100$ \\
\hline
\end{tabular}

$\mathrm{CP}=$ cleft palate with/without lip; TD= typically developing children; REVT_R= receptive vocabulary raw score of Receptive \& Expressive Vocabulary Test (Kim et al., 2009); REVT_E=expressive vocabulary raw score of Receptive \& Expressive Vocabulary Test (Kim et al., 2009); K-APP_PCC= percentage of consonants correct of Korean articulation phonology profile (Ha et al., 2021). 
확도도 $16 \%$ ile 미만에 해당하였다. 이 외에 1 명은 수용 어휘력에서 만 $10 \%$ ile 미만을 보였다. 또 다른 2명은 K-APP 자음정확도에서만 $16 \%$ ile 미만을 보였다. 학령기 구개열 아동의 개별 말-언어검사 결 과는 Appendix 1에 제시하였다.

\section{자료수집}

자료수집은 아동의 가정 또는 치료실에서 이루어졌다. 본 검사 를 실시하기 전에 학령기 구개열 아동의 인지, 말, 언어 능력을 살펴 보고자 인지검사(K-CTONI-2), 수용 및 표현 어휘력 검사(REVT), 한국 조음음운프로파일(K-APP) 중 구강구조 및 기능검사와 84개 의 자음으로 이루어진 다양한 길이의 낱말검사를 실시하였다. 이 후 본 검사인 한국어 읽기검사(KOLRA; Pae, Kim, Yoon, \& Jang, 2015)와 읽기 성취 및 읽기 인지처리 능력 검사(RA-RCP; Kim, Kim, Hwang, \& Yoo, 2014)를 실시하였다. 이때 대상자별로 음운처리 하 위검사와 읽기 하위검사순서를 무작위로 제시하였다.

본 연구에서는 음운처리 능력을 살펴보기 위해 KOLRA의 하위 검사로 음운인식, 음운기억, 빠른 자동 이름대기를 사용하였으며, 음운기억 검사의 경우 K-APP의 하위검사인 무의미 낱말 따라말하 기와 RA-RCP의 하위검사인 숫자 바로 및 거꾸로 따라말하기를 함 께 사용하였다. 음운인식 검사는 과제 유형이 탈락과 합성으로 구 성되었으며, 음운단위에 따라 음절 수준 10 문항, 음소 수준 20 문항 으로 분류되었다. 음운기억 검사는 KOLRA의 무의미 낱말 따라말 하기 과제 20 문항과 K-APP의 무의미 낱말 따라말하기 과제 25 문 항을 사용하였으며, 두 검사는 모두 2음절에서 5음절로 이루어져 있다. 그리고 RA-RCP의 숫자 바로 및 거꾸로 따라말하기는 두 검 사 모두 4 개의 숫자부터 9 개의 숫자로 구성되어 있으며, 문항 수는 숫자 개수에 따라 6 단계로 나누어져 있고 단계별 2세트씩 총 12 문 항으로 구성되어 있다. 빠른 자동 이름대기 검사는 KOLRA의 숫자 빠른 이름대기와 글자 빠른 이름대기로 구성되어 있고, 제공된 숫 자 자극의 범위는 1-5이며, 글자 자극은 '더, 재, 니, 그, 부'이다.

읽기 능력을 살펴보기 위해 KOLRA의 하위검사로 해독, 문단글 읽기 유창성, 읽기이해를 사용하였다. 먼저 해독 검사는 의미 여부 에 따라, 자소-음소 일치 여부에 따라 나누어져 있다. 문항 수는 자 소-음소 일치와 자소-음소 불일치 낱말은 각 20 문항으로 구성되어 있고, 자소-음소 일치 여부를 포함한 의미와 무의미 낱말은 각 40 문항으로 총 80 문항으로 구성되었다. 문단글 읽기 유창성 검사는 학년에 따라 제공되는 문단글의 음절 수와 주제 난이도가 다르며, 본 연구에서는 대상자 모두에게 저학년(1-2학년) 용의 '김밥 만들 기'가 제공되었다. 읽기이해 검사는 문장 및 짧은 문단 형식의 글을 읽고 총 24 문항의 빈칸을 채우도록 구성되어 있다.
모든 검사는 조용하고 개별적인 공간에서 검사자와 아동 1:1로 실 시되었다. 그리고 모든자료수집 과정은 오디오 녹음으로 기록하였다.

\section{자료분석}

자료분석은 모든 검사에서 아동의 반응을 음성 전사하였다. 먼 저 음운인식, 무의미 낱말 따라말하기, 해독 검사는 정확하게 대답 한 문항에 각각 1 점씩 부과하고 틀린 경우에는 0 점을 부과하였다. 이때 무의미 낱말 따라말하기 검사는 KOLRA와 K-APP 두 검사의 점수를 합쳐서 살펴보았다. 무의미 낱말 따라말하기, 해독, 문단글 읽기 유창성 검사에서 아동이 음운적 오류나 성문파열음, 인두마 찰음과 같은 구개열 특유의 보상조음을 보인 경우에는 KOLRA의 채점 지침 대로 0 점을 부과하였다. 그리고 문단글 읽기 유창성 검 사는 아동이 제목을 제외하고 전체 음절 수에서 오류를 보인 음절 수를 제외한 정확하게 읽은 음절 수를 첫 음절부터 마지막 음절을 모두 읽을 때까지 소요된 시간(초)으로 나눈 뒤 10 을 곱하여 아동 이 10 초당 정확하게 읽은 음절 수로 분석하였다. 숫자 바로 및 거꾸 로 따라말하기 검사는 모두 정확하게 바로 따라말하거나 거꾸로 따라말한 경우 1 점을 부과하고, 하나의 숫자라도 틀린 경우에는 0 점을 부과하였다. 빠른 자동 이름대기 검사는 아동이 숫자 또는 글 자를 보고 처음부터 끝까지 읽은 반응시간(초)을 소수점 둘째자리 에서 반올림하여 구하였다. 읽기이해 검사는 목표 반응에 해당하 게 작성한 경우 1 점을 부과하고, 그렇지 않은 경우 0 점을 부과하였 다. 이때 '그런데'와 '그래서'를 '그런대'와 '그레서'로 작성한 경우와 '그런데'를 구어체로 '근데'로 작성한 경우를 제외하고 아동이 맞춤 법 오류를 보인 경우 0 점으로 채점하였다.

\section{신뢰도}

$\mathrm{K}-\mathrm{APP}$ 의 다양한 길이의 낱말 검사, 무의미 낱말 따라말하기 검 사와 KOLRA의 해독 검사, 문단글 읽기 유창성 검사, 무의미 낱말 따라말하기 검사의 전사 및 채점 신뢰도는 전체 대상 아동 중 무작 위로 선정한 총 3 명의 자료를 바탕으로 살펴보았다. 언어병리학 전 공 대학원생 1 명과 연구자가 3 명의 자료를 각각 독립적으로 전사를 한 뒤 전사 및 채점의 일치 여부를 살펴보았다. 무의미 낱말 따라말 하기 검사는 (검사자 간 일치한 자음 수/전체 자음 수)* 100 으로, 해 독, 문단글 읽기 유창성 검사는 (검사자 간 일치한 음절 수/전체 음 절 수)* 100 으로 전사자 간 전사 신뢰도를 구하였다. 그리고 무의미 낱말 따라말하기, 해독 검사는 (검사자 간 일치한 낱말 수/전체 낱 말 수)*100으로, 문단글 읽기 유창성 검사는 (검사자 간 일치한 음 절 수/전체 음절 수)^ 100 으로 전사자 간 채점 신뢰도를 구하였다. 그 결과 전사자 간 전사 신뢰도는 95-99\%로 나타났고, 채점 신뢰도 
는 90-96\%로 나타났다.

\section{통계분석}

먼저, 집단별 종속변인에 대해 정규성 검정을 위해 KolmogorovSmirnova test를 실시한 결과, 대부분의 종속변인에서 유의확률이 .05 이상으로 나와 정규성 가정을 충족하였다. 그리고 집단별 음운 처리 검사의 각 측정치들 간의 상관관계를 살펴보았을 때, 여러 상 관계수가 .50 이상으로 서로 상관이 있다고 나타났다. 따라서 구개 열 아동과 일반 아동 간의 음운처리 하위검사(음절인식, 음소인식, 무의미 낱말 따라말하기, 숫자 따라말하기, 숫자 거꾸로 따라말하 기, 숫자 빠른 이름대기, 글자 빠른 이름대기) 수행력에서 유의미한 차이가 나타나는지 동시에 살펴보기 위해 다변량분산분석(Multivariate Analysis of Variance, MANOVA)을 실시하였다. 마찬가지 로 집단별 읽기 하위검사의 각 측정치들 간의 상관관계를 살펴보았 을 때, 대다수의 상관계수가 .90 이상으로 높은 상관관계가 나타났 다. 따라서 구개열 아동과 일반 아동 간의 읽기 하위검사(의미 낱말 해독, 무의미 낱말 해독, 자소-음소 일치형 낱말 해독, 자소-음소 불 일치형 낱말 해독, 문단글 읽기 유창성, 읽기이해) 수행력에서 유의 미한 차이가 나타나는지 동시에 살펴보기 위해 다변량분산분석을 실시하였다. 또한 부분에타제곱 $\left(\eta_{\mathrm{p}}{ }^{2}\right)$ 값을 통해 집단 간 차이에 대 한 효과크기도 살펴보았다. 집단별 수용 및 표현 어휘와 자음정확 도와 음운처리와 읽기 능력 간의 상관관계는 Pearson의 상관계수 를 토대로 살펴보았다. 모든 유의 수준은 $p<.05$ 로 설정하였다.

\section{연구결과}

\section{학령기 구개열 아동과 일반 아동 간의 음운처리 하위능력 비교}

학령기 구개열 아동과 일반 아동 간의 음운처리 능력(음절인식, 음소인식, 무의미 낱말 따라말하기, 숫자 바로 따라말하기, 숫자 거
꾸로 따라말하기, 숫자 빠른 이름대기, 글자 빠른 이름대기)을 살펴 본 결과는 Table 2 와 같다. 집단 간 차이를 검증하기 위한 다변량분 산분석 결과, 음운인식 하위검사에서 음절인식 $\left(F_{(1,19)}=13.075, p=\right.$ $\left..002, \eta_{\mathrm{p}}{ }^{2}=.395\right)$ 에서는 유의한 차이를 보였으나 음소인식 $\left(F_{(1,19)}=\right.$ $\left.3.852, p=.064, \eta_{\mathrm{p}}{ }^{2}=.161\right)$ 에서는 유의한 차이를 보이지 않았다. 음 운기억 하위검사에서는 무의미 낱말 따라말하기 $\left(F_{(1,19)}=15.439\right.$, $p=.001, \eta_{\mathrm{p}}{ }^{2}=.436$ )에서만 유의한 차이가 나타났다. 그러나 숫자 바 로 따라말하기 $\left(F_{(1,19)}=1.973, p=.175, \eta_{\mathrm{p}}{ }^{2}=.090\right)$ 와 숫자 거꾸로 따 라말하기 $\left(F_{(1,19)}=1.861, p=.188, \eta_{\mathrm{p}}{ }^{2}=.085\right)$ 에서는 모두 집단 간 유 의한 차이가 없었다. 빠른 자동 이름대기 하위검사에서 숫자 빠른 이름대기 $\left(F_{(1,19)}=.122, p=.730, \eta_{\mathrm{p}}{ }^{2}=.006\right)$ 와 글자 빠른 이름대기 $\left(F_{(1,19)}=.522, p=.478, \eta_{\mathrm{p}}{ }^{2}=.025\right)$ 에서도 모두 집단 간 유의미한 차 이를 보이지 않았다. 또한 집단 간 통계적으로 유의한 차이를 보였 던 음절인식과 무의미 낱말 따라말하기 점수를 백분율로 구하여 집단별로 제시하였다(Figure 1).

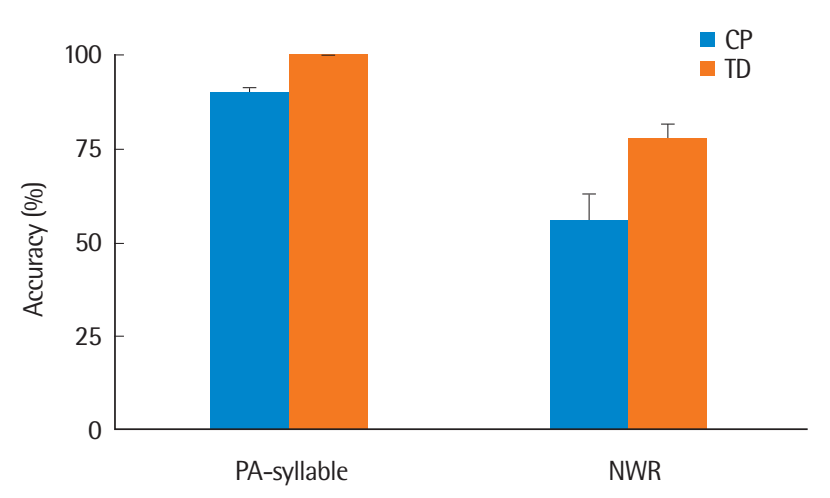

Figure 1. Percentage of correct phonological awareness and nonword repetition in the two groups.

$\mathrm{CP}=$ cleft palate with/without lip; $\mathrm{TD}=$ typically developing children; $\mathrm{PA}=$ phonological awareness; NWR=nonword repetition.

Table 2. Phonological processing ability between children with cleft palate and typically developing children

\begin{tabular}{|c|c|c|c|c|c|c|}
\hline & Possible highest scores & $\mathrm{CP}$ & TD & $F$ & $p$ & $\eta_{p}^{2}$ \\
\hline PA-syllable & 10 & 8.70 (1.25) & $10.00(0.00)$ & $13.075^{* *}$ & .002 & .395 \\
\hline PA-phoneme & 20 & $8.30(6.20)$ & $12.33(3.23)$ & 3.852 & .064 & .161 \\
\hline NWR & 45 & $25.00(7.44)$ & $34.58(3.70)$ & $15.439 * *$ & .001 & .436 \\
\hline DF & 12 & 4.90 (1.91) & $6.00(1.76)$ & 1.973 & .175 & .090 \\
\hline DB & 12 & 1.70 (1.34) & $2.67(1.88)$ & 1.861 & .188 & .085 \\
\hline RAN-number (sec) & & $29.45(6.82)$ & $28.41(7.07)$ & .122 & .730 & .006 \\
\hline RAN-letter (sec) & & $29.97(8.22)$ & 27.41 (8.33) & .522 & .478 & .025 \\
\hline
\end{tabular}

$\mathrm{CP}=$ cleft palate with/without lip; $\mathrm{TD}=$ typically developing children; $\mathrm{PA}=$ phonological awareness; NWR=nonword repetition; $\mathrm{DF}=$ digit forward recall task; $\mathrm{DB}=$ digit backward recall task; $\mathrm{RAN}=$ rapid automatized naming.

${ }^{* *} p<.01$. 
Table 3. Reading ability between children with cleft palate and typically developing children

\begin{tabular}{lcccccc}
\hline & Possible highest scores & CP & TD & $F$ & $p$ & $\eta_{\mathrm{p}}{ }^{2}$ \\
\hline DT & 80 & $44.30(15.11)$ & $59.17(5.75)$ & $9.972^{* *}$ & .005 & .333 \\
P-G CD & 40 & $29.00(7.47)$ & $36.92(3.00)$ & $11.378^{* *}$ & .003 & .363 \\
P-G NCD & 40 & $15.30(8.72)$ & $22.25(3.55)$ & $6.408^{*}$ & .020 & .243 \\
WD & 40 & $23.60(8.29)$ & $32.08(3.40)$ & $10.534^{* *}$ & .004 & .345 \\
NWD & 40 & $20.70(7.13)$ & $27.08(3.34)$ & $7.651^{*}$ & .012 & .277 \\
RF (\# of syllables per second) & - & $22.31(11.04)$ & $30.32(7.27)$ & 4.175 & .054 & .173 \\
RC & 24 & $4.50(3.72)$ & $9.17(3.16)$ & $10.146^{* *}$ & .005 & .337 \\
\hline
\end{tabular}

$\mathrm{CP}=$ cleft palate with/without lip; $\mathrm{TD}=$ typically developing children; $\mathrm{DT}=$ decoding total; $\mathrm{P}-\mathrm{G} \mathrm{CD}=$ phoneme-grapheme correspondent words decoding; $\mathrm{P}-\mathrm{G} \mathrm{NCD}=$ phonemegrapheme non-correspondent words decoding; $\mathrm{WD}=$ word decoding; $\mathrm{NWD}=$ nonword decoding; $\mathrm{RF}=$ reading fluency; $\mathrm{RC}=$ reading comprehension.

${ }^{*} p<.05,{ }^{* *} p<.01$.

Table 4. Correlations among REVT-R, REVT-E, and PCC and phonological processing and reading abilities in CP group

\begin{tabular}{|c|c|c|c|c|c|c|c|c|c|c|c|c|c|c|}
\hline & \multicolumn{7}{|c|}{ Phonological processing } & \multicolumn{7}{|c|}{ Reading } \\
\hline & PA-syllable & PA-phoneme & RAN-number & RAN-letter & NWR & DF & $\mathrm{DB}$ & P-G CD & P-G NCD & WD & NWD & DT & $\mathrm{RC}$ & RF \\
\hline REVT_E & .47 & $.69^{*}$ & .18 & .28 & .57 & .55 & .01 & .57 & .30 & .40 & .50 & .46 & .60 & .34 \\
\hline REVT_R & .22 & $.64^{*}$ & .28 & .13 & $.81^{* *}$ & $.68^{*}$ & .07 & .62 & .59 & .61 & $.66^{*}$ & $.64^{*}$ & $.72^{*}$ & .43 \\
\hline PCC & .19 & .20 & .45 & .24 & $.88^{* *}$ & .35 & .58 & $.81^{* *}$ & $.64^{*}$ & $.78^{* *}$ & $.72^{*}$ & $.77^{* *}$ & .41 & .45 \\
\hline
\end{tabular}

$\mathrm{CP}=$ cleft palate with/without lip; $\mathrm{PA}=$ phonological awareness; $\mathrm{RAN}=$ rapid automatized naming; $\mathrm{NWR}=$ non-word repetition; $\mathrm{DF}=$ digit forward recall task; $\mathrm{DB}=$ digit backward recall task; P-G CD= phoneme-grapheme correspondent words decoding; $\mathrm{P}-\mathrm{G} \mathrm{NCD}=$ phoneme-grapheme non-correspondent words decoding; WD=word decoding; $\mathrm{NWD}=$ nonword decoding; $\mathrm{DT}=$ decoding total; $\mathrm{RC}=$ reading comprehension; $\mathrm{RF}=$ reading fluency. ${ }^{*} p<.05,{ }^{* *} p<.01$.

\section{학령기 구개열 아동과 일반 아동 간의 읽기 하위능력 비교}

학령기 구개열 아동과 일반 아동 간의 읽기 능력(해독, 문단글 읽 기 유창성, 읽기 이해)을 살펴본 결과는 Table 3과 같다. 해독 검사 에서는 자소-음소 일치형 낱말, 자소-음소 불일치형 낱말, 의미 낱 말, 무의미 낱말의 영역별 점수와 총점을 구하였다. 집단 간 차이를 검증하기 위한 다변량분산분석 결과, 해독 총점 $\left(F_{(1,19)}=9.972, p=\right.$ $\left..005, \eta_{p}^{2}=.333\right)$, 자소-음소 일치 낱말 해독 $\left(F_{(1,19)}=11.378, p=.003\right.$, $\left.\eta_{\mathrm{p}}{ }^{2}=.363\right)$, 자소-음소 불일치 낱말 해독 $\left(F_{(1,19)}=6.408, p=.020\right.$, $\left.\eta_{\mathrm{p}}{ }^{2}=.243\right)$, 의미 낱말 해독 $\left(F_{(1,19)}=10.534, p=.004, \eta_{\mathrm{p}}{ }^{2}=.345\right)$, 무의 미 낱말 해독 $\left(F_{(1,19)}=7.651, p=.012, \eta_{\mathrm{p}}^{2}=.277\right)$, 읽기이해 $\left(F_{(1,19)}=10.146\right.$, $\left.p=.005, \eta_{\mathrm{p}}{ }^{2}=.337\right)$ 에서 모두 유의한 차이를 보였다. 그러나 문단글 읽기 유창성 $\left(F_{(1,19)}=4.175, p=.054, \eta_{\mathrm{p}}{ }^{2}=.173\right)$ 에서는 유의한 차이 가 없었다. 또한 집단 간 통계적으로 유의한 차이를 보였던 해독 검 사의 영역별 점수와 총점, 읽기이해 점수를 백분율로 구하여 집단 별로 비교 제시하였다(Figure 2).

해독 검사에서는 총점을 포함하여 모든 세부 영역 점수에서 집 단 간 유의한 차이가 나타났다. 두 집단 간 해독 검사에서 보인 오류 의 유형이 어떠한지 살펴본 결과, 구개열 아동은 대치(35\%), 첨가 (15\%), 자소-음소 불일치형 낱말에서 음운 규칙을 적용하지 않고 글자 그대로 읽는 오류(15\%), 생략(12\%) 순으로 나타났고, 일반 아

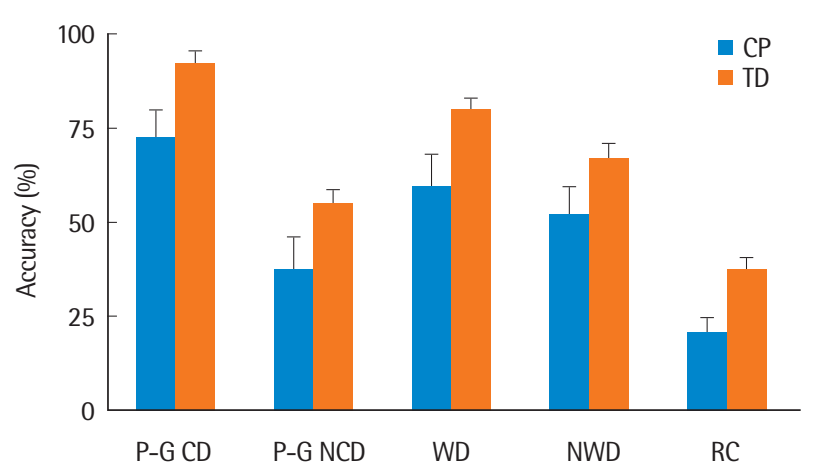

Figure 2. Percentage of correct decodings and reading comprehension in the two groups.

$\mathrm{CP}=$ cleft palate with/without lip; $\mathrm{TD}=$ typically developing children; $\mathrm{P}-\mathrm{G} \mathrm{CD}=$ phoneme-grapheme correspondent words decoding; $\mathrm{P}-\mathrm{G} \mathrm{NCD}=$ phoneme-grapheme non-correspondent words decoding; $W D=$ word decoding; $N W D=$ nonword decoding; $\mathrm{RC}=$ reading comprehension.

동은 글자 그대로 읽는 오류(35\%), 대치(33\%), 첨가(20\%) 순으로 나 타났다. 구개열 아동은 보상조음과 치간음화와 같은 왜곡 오류를 포함한 조음 오류가 전체 비율의 $16 \%$ 를 차지하였으나 일반 아동은 $2 \%$ 로 적게 나타났다.

\section{집단별 어휘, 말, 음운처리, 읽기 능력 간의 상관관계}

구개열 아동 집단과 일반 아동 집단에서 수용 및 표현 어휘력과 
Table 5. Correlations among REVT-R, REVT-E, PCC, Phonological processing ability, and Reading ability in TD group

\begin{tabular}{|c|c|c|c|c|c|c|c|c|c|c|c|c|c|c|}
\hline & \multicolumn{7}{|c|}{ Phonological processing } & \multicolumn{7}{|c|}{ Reading } \\
\hline & PA-syllable & PA-phoneme & RAN-number & RAN-letter & NWR & $\mathrm{DF}$ & $\mathrm{DB}$ & $P-G C D$ & P-G NCD & WD & NWD & DT & $\mathrm{RC}$ & $\mathrm{RF}$ \\
\hline REVT_E & - & .40 & .57 & .47 & -.21 & -.02 & -.02 & -.10 & -.04 & .29 & -.44 & -.08 & $.58^{*}$ & $<.01$ \\
\hline REVT_R & - & $<.01$ & .42 & .43 & -.13 & .24 & .04 & -.11 & -.10 & .10 & -.30 & -.12 & $.67^{*}$ & -.39 \\
\hline PCC & - & $.58^{*}$ & .11 & -.06 & .29 & -.05 & .45 & $.67^{*}$ & .41 & .58 & .44 & $.60^{*}$ & -.13 & $.68^{*}$ \\
\hline
\end{tabular}

$\mathrm{TD}$ = typically developing children; $\mathrm{PA}=$ phonological awareness; $\mathrm{RAN}=$ rapid automatized naming; $\mathrm{NWR}=$ non-word repetition; $\mathrm{DF}=$ digit forward recall task; $\mathrm{DB}=$ digit backward recall task; P-G CD= phoneme-grapheme correspondent words decoding; P-G NCD= phoneme-grapheme non-correspondent words decoding; WD=word decoding; $\mathrm{NWD}=$ nonword decoding; $\mathrm{DT}=$ decoding total; $\mathrm{RC}=$ reading comprehension; $\mathrm{RF}=$ reading fluency. ${ }^{*} p<.05$.

자음정확도, 음운처리 능력과 읽기 능력 간의 상관관계를 살펴보 았다(Tables 4, 5). 구개열 아동의 경우 표현 어휘 원점수는 음소인 식과 .69로 높은 상관관계를 보였다 $(p<.05)$. 수용 어휘 원점수는 음 소인식, 숫자 바로 따라말하기, 무의미 낱말 해독, 해독 총점, 읽기이 해 간에 높은 상관관계를 보였다 $(p<.05)$. 특히 무의미 낱말 따라말 하기는 수용어휘 원점수와 .81로 가장 높은 상관관계를 보였다 ( $p<.01)$. 자음정확도는 자소-음소 불일치형 낱말 해독, 무의미 낱말 해독 간에 높은 상관관계를 보였다 $(p<.05)$. 특히 무의미 낱말 따라 말하기, 자소-음소 일치형 낱말 해독, 의미 낱말 해독, 해독 총점은 자음정확도와 가장 높은 상관관계를 보였다 $(p<.01)$. 일반 아동 집 단은 음절 수준의 음운인식에서 모든 아동이 $100 \%$ 의 정확도를 보 여 상관관계 분석을 할 수 없었다. 일반 아동은 표현 및 수용 어휘 원점수는 모두 읽기이해와 $.58, .67$ 로 높은 상관관계를 보였고, 자 음정확도는 음소인식, 자소-음소 일치형 낱말 해독, 해독 총점, 읽 기유창성과 높은 상관관계를 보였다 $(p<.05)$. 구개열 아동과 마찬 가지로 일반 아동도 자음정확도와 자소-음소 일치형 낱말 해독, 해 독총점 간에 높은 상관관계를 보였다 $(p<.05)$.

\section{논의 및 결론}

본 연구는 학령전기에 말소리장애를 보였던 초등학교 1,2 학년의 구개열 아동이 일반 아동과 비교하여 음운인식, 음운기억, 빠른 자 동 이름대기 과제로 측정된 음운처리 능력과 해독, 읽기 유창성, 읽 기이해 과제로 측정된 읽기 능력이 어떠한지 살펴보았다. 또한 어휘 력, 말 정확도와 음운처리 및 읽기 능력 간의 상관관계를 집단별로 살펴봄으로써 학령기 구개열 아동이 보이는 음운처리와 읽기 상의 문제의 본질과 특성을 이해하고자 하였다. 먼저 음운처리에서 집단 별 음운 단위에 따른 음운인식 정확도를 살펴보면, 음절 수준에서 모든 일반 아동은 $100 \%$ 의 정확도를 보인 반면에 구개열 아동은 평 균 $87 \%$ 의 정확도를 보여 집단 간 유의한 차이가 나타났다. 초등학 교 1-2학년이 되면 음절 수준에서의 음운인식에는 일반적으로 어
려움이 없으나 일부 구개열 아동은 여전히 음절 수준에서의 음운 인식에 어려움을 보였다. 음소 수준에서의 음운인식은 구개열 아동 이 $42 \%$, 일반 아동이 $62 \%$ 로 나타나 구개열 아동이 더 낮은 수행력 을 보였으나 집단 간 유의한 차이는 나타나지 않았다. 6세, 초등학 교 2, 4학년을 대상으로 음운인식 발달을 살펴본 Kim과 Pae (2007) 의 연구에서 음절 수준의 음운인식은 6세가 $84 \%, 2$ 학년이 $98 \%$ 의 정확도를 보였다. 음소 수준의 음운인식에서는 6 세가 $24 \%, 2$ 학년 이 $38 \%, 4$ 학년이 $76 \%$ 의 정확도를 보여 초등학교 저학년까지도 저 조한 음소인식 능력을 보인다고 보고하였다. 본 연구에서도 선행연 구와 일관성있게 일반 아동도 음소 수준에서의 음운인식이 아직 완전하게 발달되지 않아 집단 간 유의한 차이를 보이지 않았다. 그 러나 일반 아동에 비해 구개열 아동은 음소 뿐만 아니라 음절 수준 에서의 음운인식이 늦게 발달하거나 어려움을 보일 가능성이 높음 을 연구결과가 제시하므로 저학년 이후에도 음운인식 능력에 대한 평가를 실시하여 수행력을 지속적으로 살펴볼 필요가 있겠다.

음운기억 하위검사에서는 무의미 낱말 따라말하기에서만 집단 간 유의한 차이가 나타났다. 이는 구개열 아동이 무의미 낱말 따라 말하기와 같은 음운기억 능력에서 끝까지 결함을 보인다고 제시하 였던 선행연구들과 유사한 결과였다(Bishop \& Snowling, 2004; Collett, Leroux et al., 2010). 특히 Bisschop (2011)은 구개열 아동은 의미와 무의미 낱말 모두에서 따라말하기 상의 어려움을 보이는 것으로 나타났다. 연구자는 구개열 아동이 음성 부호화와 조음에 서 결함을 보이고, 잘못된 음운지각과 음운표상으로 인해 음운기 억 상의 문제를 보일 수 있다고 해석하였다. 본 연구에서도 구개열 아동이 조음, 말 지각, 음운표상, 음운기억 등에서 결함을 보여 무의 미 낱말 따라말하기 상의 어려움을 보였을 가능성이 크다는 점을 시사하고 있다. 특히 음운기억 하위검사 중 숫자 바로 및 거꾸로 따 라말하기에서는 집단 간 유의한 차이가 나오지 않은 반면, 무의미 낱말 따라말하기에서만 집단 간 유의한 차이가 나타난 연구결과에 주목할 필요가 있다. 이는 단순히 숫자를 듣고 기억하여 따라말하 거나 숫자를 거꾸로 배열하면서 작업기억이 요구되는 숫자 바로 및 
거꾸로 따라말하기 과제에 비해 무의미 낱말 따라말하기 과제에서 는 말 지각, 청각적 음운기억, 음운표상, 말 운동 프로그램과 같이 광범위한 말-언어적 처리가 보다 더 요구되기 때문이다(Bisschop, 2011; Ha, 2020). 따라서 본 연구결과는 구개열 아동은 단순히 음운 단기기억과 작업기억상에 어려움보다는 보다 더 광범위한 말-언어 처리상의 제한을 보임을 시사하고 있다.

본 연구의 구개열 아동 10 명 중 6 명이 여전히 말-언어문제를 보이 는 것으로 나타났다. Ha (2020)는 언어장애를 동반한 말소리장애 아동이 유의하게 낮은 무의미 낱말 따라말하기 수행력을 보여 말언어처리 과정의 전반에 걸쳐 광범위한 결함이 있고, 이는 아동이 보이는 말과 언어상의 문제와 관련되어 있음을 제시하였다. 따라서 학령기 구개열 아동이 말-언어문제를 지속적으로 보인다면 말 지 각, 음운 부호화, 음운표상, 음운기억, 말-운동 프로그램과 관련된 말 처리 과정에서 광범위한 결함이 있음을 시사한다. 일반적으로 구개열 아동이 영유아기에 중이염에 자주 걸리고, 보상조음 등 특 유의 발음 오류를 보이는 점을 고려한다면 말 지각에서부터 결함 을 보였을 가능성이 있다. 그러므로 후속연구에서는 구개열 아동 의 말 지각 능력을 평가하여 말-언어처리 과정에서 어떠한 단계에 서 결함을 보이는지 구체적으로 살펴볼 필요가 있다.

음운처리 중 숫자 및 글자 빠른 이름대기 과제에서 모두 집단 간 유의한 차이가 나타나지 않았다. 읽기장애 유무에 따른 구개열 아 동 집단 간의 표현 어휘력, 음소인식, 빠른 이름대기 수행력을 살펴 본 Richman과 Ryan (2003)은 구개열 아동의 빠른 자동 이름대기 능력이 이후 학령기 읽기 문제와 중요한 연관성을 가지는 요인이라 고 주장하였다. 본 연구에서는 학령전기에 말소리장애를 보인 구개 열 아동이 빠른 이름대기 능력은 상대적으로 양호하고, 음운인식 과 무의미 낱말 따라말하기 능력이 떨어져 학령기에 보이는 읽기 능력과 보다 더 관련이 있다는 점을 시사한다.

읽기 하위능력 중 읽기 유창성을 제외한 나머지 모든 측정치(해 독 총점, 자소-음소 일치 및 불일치 낱말 해독, 의미 및 무의미 낱말 해독, 읽기이해)에서 집단 간 유의미한 차이가 나타났다. 이는 구개 열 아동이 일반 아동보다 기본적인 읽기 능력에서 어려움을 보인다 고 제시하였던 다수의 선행연구와 유사한 결과였다(Broder, Richman, \& Matheson, 1998; Richman, Eliason, \& Lindgren, 1988). 또 한 본 연구에 참여한 구개열 아동 모두 학령전기에 말 문제를 보였 으며 이 중 일부는 학령기에도 말-언어 문제를 지속적으로 보이고 있었음을 고려한다면 말소리장애 아동이 4-5세 이후에도 지속적 으로 말 문제를 보인다면 읽기 문제를 보일 가능성이 크다고 주장 한 많은 선행연구와도 일관성이 있다(Bird et al., 1995; Larrivee \& Catts, 1999; Nathan et al., 2004). 집단별 각 읽기 하위검사에 대한
정확도를 살펴보면 자소-음소 일치형 낱말 해독에서는 구개열 아 동이 $73 \%$ 로, 일반 아동이 $92 \%$ 로 나타났고, 자소-음소 불일치형 낱 말 해독에서는 구개열 아동이 $38 \%$, 일반 아동이 $55 \%$ 로 나타났다. 그리고 의미 낱말 해독 정확도에서는 구개열 집단이 $59 \%$, 일반 집단 이 $80 \%$ 로 나타났고, 무의미 낱말 해독에서는 구개열 집단이 $52 \%$, 일반 집단이 $68 \%$ 로 나타났다. 즉 본 연구에서는 구개열 아동이 일 반 아동보다 특히 시각적, 음운적으로 비친숙한 낱말뿐만 아니라 친숙한 낱말을 읽는 것에서도 제한을 보여 해독 상의 발달 지연을 보였다. 또한 집단별 해독 검사에서의 오류 유형을 살펴보았을 때, 일반 아동은 대부분 대치, 첨가, 글자 그대로 읽는 오류를 보였다. 구 개열 아동은 왜곡 또는 보상조음과 같이 구개열 특유의 조음 오류 를 보이기는 했으나 대치, 첨가, 생략, 삽입, 음운 규칙을 적용하지 못하고 글자를 그대로 읽는 해독 상의 오류도 전체 오류에서 $84 \%$ 를 차지하였다. 따라서 학령기까지 말 문제를 계속 보이는 구개열 아동의 경우 조음 상의 문제로 인해 문자 해독 능력이 과소평가될 가능성을 배제하기는 어렵지만, 근본적으로 문자 해독 상에 어려 움을 보인다고 할 수 있다.

다음으로, 읽기 이해 과제의 정확도는 구개열 집단이 $19 \%$, 일반 아동이 $38 \%$ 로 나타나 구개열 아동이 현저하게 낮은 수행력을 보였 다. Richman 등(1988)은 6-13세 구개열 아동의 연령과 파열유형에 따라 읽기이해력을 살펴봤을 때, 6-7세와 8-9세 구개열 집단에서 파 열유형에 상관없이 유의하게 저조한 읽기이해력을 보였다고 제시 하였다. 이는 본 연구와 유사한 결과로, 학령기 구개열 아동 특히 학 령전기에 말과 언어상의 발달 지연을 보였던 구개열 아동이 음운처 리와 문자 해독뿐만 아니라 읽기이해 측면에서도 어려움을 보인다 고 제안할 수 있다. 마지막으로 읽기 유창성 능력을 살펴봤을 때, 통 계적으로 집단 간 유의한 차이는 나타나지 않았다. 읽기 유창성은 앞서 살펴본 빠른 이름대기와 함께, 글자나 낱말을 해독할 때 정확 하고 자동화되어 빠르게 읽는 것으로 정의된다(Kuhn \& Stahl, 2003; Wagner et al., 1997). 특히 두 과제는 나머지 읽기 과제에 비 해 읽기 정확성뿐만 아니라 처리 속도가 중요하게 요구된다. 본 연 구에서는 읽기 유창성과 빠른 이름대기 과제에서 집단 간 통계적 으로 유의한 차이가 나타나지 않았으나, 나머지 음운처리 및 읽기 과제에서는 모두 집단 간 유의한 차이가 나타났다. 즉 학령기에 말언어문제를 지속적으로 보이는 구개열 아동의 경우 음운인식 및 문자 해독과 읽기이해에서는 어려움을 보이지만, 문자에 대한 처리 속도 상에는 어려움이 없다고 할 수 있다. 후속연구에서는 더 많은 수의 학령기 구개열 아동을 대상으로 읽기 유창성 측면을 자세히 살펴보면서 구개열 아동의 읽기 상의 강-약점을 보다 면밀히 살펴 볼 필요가 있다. 
구개열 아동과 일반 아동 집단에서 어휘, 말, 음운처리, 읽기 능력 간의 상관관계를 살펴본 결과, 구개열 아동의 음운처리 및 읽기 능 력은 일반 아동에 비해 수용 및 표현 어휘력과 자음정확도의 여러 가지 영역에서 높은 상관관계를 보였다. 구개열 아동의 표현 어휘력 은 음소인식과 유의한 상관관계를 보였으며, 수용 어휘력은 음소인 식, 무의미 낱말 따라말하기, 숫자 바로 따라말하기, 무의미 낱말 해 독, 해독 총점, 읽기이해 간에 높은 상관관계를 보였다. 특히 무의미 낱말 따라말하기는 수용 어휘 원점수와 .81로 가장 높은 상관관계 를 보였다. 자음정확도는 읽기 영역에서는 모든 해독 점수와 높은 상관관계를 보였으며, 음운처리 영역에서는 무의미 낱말 따라말하 기와 .88로 가장 높은 상관관계를 보였다. 이러한 결과는 구개열 아 동이 보이는 음운처리 및 읽기 능력 상의 어려움이 언어와 말 산출 능력과 직접적으로 관련이 있으며, 일반적인 언어와 말소리장애 아 동을 대상으로 무의미 낱말 따라말하기의 수행력을 살펴본 연구결 과와 일관성이 있는 결과라 할 수 있다(Botting \& Conti-Ramsden, 2001; Gatergole \& Baddeley, 1990; Gray, 2006; Ha, 2020; Kim, Son, \& Yim, 2020; Lisa \& Gathercole, 2006; Yang, Yim, Kim, \& Han, 2013).

반면 본 연구는 학령기 구개열 아동이 일반 아동과 유사하거나 오히려 더 높은 읽기 능력을 보였다고 제시하였던 선행연구와 일치 하지 않는 결과를 보였다(Chapman, 2011; Collett, Leroux et al., 2010; Collett, Stott-Miller et al., 2010). 본 연구와 선행연구 결과 상 의 불일치는 연구 대상자의 특성과 관련이 있을 수 있다. Collett와 Leroux 등(2010)은 종단연구에 참여한 구개열 아동의 부모가 5세 때 아동의 언어와 초기 읽기 능력을 확인하고 조기에 언어치료를 받았고, 그 영향으로 7세 때 기본적인 읽기 능력에서 일반 아동과 차이가 감소되었을 가능성이 있다고 제시하였다. 그러나 본 연구에 서는 10 명의 모든 구개열 아동이 학령전기에 말과 언어문제를 보여 언어치료를 권고받았으나 실제로 5명만이 언어치료를 받았으며, 이 중 4명은 학령기에도 말-언어문제가 완전하게 해결되지 않아 언 어치료를 지속적으로 받고 있었다. 수용 및 표현 어휘력, 자음정확 도 상의 집단 간 유의한 차이는 없었으나 구개열 아동 10 명 중 6명 은 학령기에 이르러서도 수용 및 표현 어휘력 상의 지연을 보이거나 자음정확도가 떨어지는 것으로 나타났다. 따라서 본 연구결과는 구개열 아동은 선천적 조음기제의 결함과 중이염 등으로 학령전기 에 말-언어 문제를 보일 가능성이 높으며, 이러한 학령전기의 문제 는 이후 음운처리와 읽기 능력상의 발달에 부정적인 영향을 끼쳐 학령기에 지속적인 어려움을 보일 수 있음을 제안하고 있다. 그러 므로 구개열 아동에게 학령전기에 지속적인 말-언어 발달에 대한 모니터링과 조기 중재를 제공하고 4-5세 이후에는 음운처리 능력
에 대한 평가를 통해 읽기 문제의 가능성을 예측하고, 필요하다면 음운처리 및 기본적인 읽기 능력 향상을 목표로 한 중재를 제공하 여 이후 학령기에 나타날수 있는 읽기 문제를 예방해야 한다.

본 연구는 학령전기에 말-언어상의 문제를 보였던 구개열 아동 을 대상으로 학령기 음운처리와 읽기 능력을 살펴본 연구로 구개열 아동이 학령기에 음운처리 및 읽기 상에 어려움을 보일 가능성이 높으므로 지속적이고 적극적인 평가와 중재가 필요함을 제시한다 는 점에서 의미가 있다. 그러나 본 연구의 대상자 수가 적어, 학령기 구개열 아동을 대표할 수 있는 결과라고 해석하기에는 다소 제한 이 있다. 따라서 추후 지속적인 연구를 통해 학령기 구개열 아동의 음운처리 및 읽기 능력을 보다 체계적으로 살펴보아야 할 것이다. 음운처리와 읽기의 모든 영역에서 어려움을 보이는 것이 아니라 무 의미 낱말 따라말하기, 문자 해독, 읽기 이해 상의 어려움을 보인다 는 본 연구결과를 고려한다면 다양한 음운처리 및 읽기 영역 중에 서 구개열 아동이 상대적으로 양호하거나 취약한 영역을 파악하는 연구가 필요하다. 또한 구개열 집단의 경우 파열 유형에 따라서도 읽기장애 발생률과 능력에서 유의한 차이가 나타날수 있다는 선행 연구(Richman et al., 1988)를 토대로 구개열 유형에 따라 읽기장애 발생률과 장애 정도가 다른지 자세히 살펴볼 필요가 있겠다.

\section{REFERENCES}

Ackerman, P. T., \& Dykman, R. A. (1993). Phonological processes, confrontational naming, and immediate memory in dyslexia. Journal of Learning Disabilities, 26(9), 597-609.

Alighieri, C., Bettens, K., Adriaansen, A., Nevenjans, E., Malfroid, A., \& Van Lierde, K. (2020). Technical reading and writing skills and their relationship with linguistic processes in children with a cleft (lip and) palate: a comparison with peers. Folia Phoniatrica et Logopaedica, 1-11.

Bird, J., Bishop, D. V., \& Freeman, N. H. (1995). Phonological awareness and literacy development in children with expressive phonological impairments. Journal of Speech, Language, and Hearing Research, 38(2), 446-462.

Bishop, D. V., \& Adams, C. (1990). A prospective study of the relationship between specific language impairment, phonological disorders and reading retardation. Journal of Child Psychology and Psychiatry, 31(7), 10271050.

Bishop, D. V., \& Snowling, M. J. (2004). Developmental dyslexia and specific language impairment: same or different?. Psychological Bulletin, 130(6), 858-886.

Bisschop, M. T. (2011). Non-word repetition in children with cleft palate: a re- 
lation between phonological memory and vocabulary (Master's thesis). Universitiet Utrecht, Utrecht, Netherlands.

Botting, N., \& Conti-Ramsden, G. (2001). Non-word repetition and language development in children with specific language impairment (SLI). International Journal of Language \& Communication Disorders, 36(4), 421432.

Bradley, L., \& Bryant, P. E. (1983). Categorizing sounds and learning to reada causal connection. Nature, 301(5899), 419-421.

Broder, H. L., Richman, L. C., \& Matheson, P. B. (1998). Learning disability, school achievement, and grade retention among children with cleft: a twocenter study. Cleft Palate-Craniofacial Journal, 35(2), 127-131.

Broen, P. A., Devers, M. C., Doyle, S. S., Prouty, J. M., \& Moller, K. T. (1998). Acquisition of linguistic and cognitive skills by children with cleft palate. Journal of Speech, Language, and Hearing Research, 41(3), 676-687.

Ceponiene, R., Haapanen, M. L., Ranta, R., Naatanen, R., \& Hukki, J. (2002). Auditory sensory impairment in children with oral clefts as indexed by auditory event-related potentials. The Journal of Craniofacial Surgery, 13(4), $554-566$.

Chapman, K. L. (1991). Vocalizations of toddlers with cleft lip and palate. Cleft Palate-Craniofacial Journal, 28(2), 172-178.

Chapman, K. L. (1993). Phonologic processes in children with cleft palate. The Cleft Palate-Craniofacial Journal, 30(1), 64-72.

Chapman, K. L. (2011). The relationship between early reading skills and speech and language performance in young children with cleft lip and palate. The Cleft Palate-Craniofacial Journal, 48(3), 301-311.

Chapman, K. L., Graham, K. T., Gooch, J., \& Visconti, C. (1998). Conversational skills of preschool and school-age children with cleft lip and palate. The Cleft Palate-Craniofacial Journal, 35(6), 503-516.

Collett, B. R., Leroux, B., \& Speltz, M. L. (2010). Language and early reading among children with orofacial clefts. The Cleft Palate-Craniofacial Journal, 47(3), 284-292.

Collett, B. R., Stott-Miller, M., Cunningham, M., Kapp-Simon, K., \& Speltz, M. L. (2010). Reading and related skills in children with orofacial clefts. Journal of Pediatric Psychology, 35(2), 199-208.

Conrad, A. L., McCoy, T. E., DeVolder, I., Richman, L. C., \& Nopoulos, P. (2014). Reading in subjects with an oral cleft: speech, hearing and neuropsychological skills. Neuropsychology, 28(3), 415-422.

Cormier, P., \& Dea, S. (1997). Distinctive patterns of relationship of phonological awareness and working memory with reading development. Reading and Writing, 9(3), 193-206.
Chapman, K. L. (1991). Vocalizations of toddlers with cleft lip and palate. The Cleft Palate-Craniofacial Journal, 28(2), 172-178.

Chapman, K. L. (1993). Phonologic processes in children with cleft palate. The Cleft Palate-Craniofacial Journal, 30(1), 64-72.

Chapman, K. L. (2011). The relationship between early reading skills and speech and language performance in young children with cleft lip and palate. The Cleft Palate-Craniofacial Journal, 48(3), 301-311.

Chapman, K. L., Graham, K. T., Gooch, J., \& Visconti, C. (1998). Conversational skills of preschool and school-age children with cleft lip and palate. The Cleft Palate-Craniofacial Journal, 35(6), 503-516.

Eliason, M. J., \& Richman, L. C. (1990). Language development in preschoolers with cleft. Developmental Neuropsychology, 6(2), 173-182.

Gathercole, S. E., \& Baddeley, A. D. (1990). Phonological memory deficits in language disordered children: is there a causal connection?. Journal of Memory and Language, 29(3), 336-360.

Gray, S. (2006). The relationship between phonological memory, receptive vocabulary, and fast mapping in young children with specific language impairment. Journal of Speech, Language and Hearing Research, 49(5), 955969.

Ha, S. (2019). Onset of canonical babbling in children with and without cleft palate. Communication Sciences \& Disorders, 24(3), 715-723.

Ha, S. (2020). Nonword repetition in terms of subtypes of children with speech sound disorders. Communication Sciences \& Disorders, 25(4), 929-937.

Ha, S., Kim, M., Seo, D., \& Pi, M. (2021). Korean Articulation Phonology Profile $(K-A P P)$. Seoul: Human Brain Research and Consulting.

Ha, S., Jung, S., Koh, K. S., \& Oh, T. S. (2018). Speech outcomes of Korean children with bilateral cleft lip and palate following primary palatal surgery. Communication Sciences \& Disorders, 23(4), 982-991.

Han, J. S., \& Sim, H. S. (2008). Comparisons of the percentage of correct consonants, speech intelligibility, and speech acceptability among children with cleft palate, children with functional articulation disorder, and normally developing children. Korean Journal of Communication \& Disorders, 13(3), 454-476.

Hardin-Jones, M. A., \& Jones, D. L. (2005). Speech production of preschoolers with cleft palate. The Cleft Palate-Craniofacial Journal, 42(1), 7-13.

Kim, A., Kim, U., Hwang, M., \& Yoo, H. (2014). Test of reading achievement and reading cognitive processes ability $(R A-R C P)$. Seoul: Hakjisa.

Kim, M. B., \& Pae, S. (2007). Word recognition and phonological awareness of kindergartener, second and fourth graders. Journal of Speech-Language \& Hearing Disorder, 16(2), 89-107. 
Kim, S., Son, J., \& Yim, D. (2020). Effects of phonological awareness and phonological processing on language skills in 4-to 6-year old children with and without language delay. Phonetics and Speech Sciences, 12(1), 51-63.

Kim, Y. T., Hong, G. H., Kim, K. H., Jang, H. S., \& Lee, J. Y. (2009). Receptive \& expressive vocabulary test (REVT). Seoul: Seoul Community Rehabilitation Center.

Kuehn, D. P., \& Moller, K. T. (2000). Speech and language issues in the cleft palate population: the state of the art. The Cleft Palate-Craniofacial Journal, $37(4), 1-35$.

Kuhn, M. R., \& Stahl, S. A. (2003). Fluency: a review of developmental and remedial practices. Journal of Educational Psychology, 95(1), 3-21.

Larrivee, L. S., \& Catts, H. W. (1999). Early reading achievement in children with expressive phonological disorders. American Journal of Speech-Language Pathology, 8(2), 118-128.

Lee, H. J., Kim, Y. T., \& Hwang, B. H. (2018). Phonological processing and language skills in preschool children with speech sound disorders according to phonological awareness skills. Journal of Speech-Language \& Hearing Disorder, 27(4), 69-77.

Lisa, M., \& Gathercole, S. (2006). Short-term and working memory in specific language impairment. International Journal of Language and Communication Disorders, 41(6), 675-693.

Nathan, L., Stackhouse, J., Goulandris, N., \& Snowling, M. J. (2004). The development of early literacy skills among children with speech difficulties. Journal of Speech, Language, and Hearing Research, 47(2), 377-391.

Pae, S., Kim, M., Yoon, H. J., \& Jang, S. (2015). Korean Language Based Reading Assessment (KOLRA). Seoul: Hakjisa.

Park, H. (2014). Korean version of Comprehensive Test of Nonverbal Intelligence Second Edition (K-CTONI-2). Seoul: Mindpress.

Pi, M., \& Ha, S. (2017). Phonological characteristics of early vocabulary among children with cleft palate, late talking children, and typically developing children. Communication Sciences \& Disorders, 22(2), 328-340.
Richman, L. C., \& Eliason, M. J. (1984). Type of reading disability related to cleft type and neuropsychological patterns. Cleft Palate Journal, 21(1), 1-6.

Richman, L. C., Eliason, M. J., \& Lindgren, S. D. (1988). Reading disability in children with clefts. Cleft Palate Journal, 25(1), 21-5.

Richman, L. C., \& Ryan, S. M. (2003). Do the reading disabilities of children with cleft fit into current models of developmental dyslexia?. The Cleft Palate-Craniofacial Journal, 40(2), 154-157.

Richman, L. C., Wilgenbusch, T., \& Hall, T. (2005). Spontaneous verbal labeling: visual memory and reading ability in children with cleft. The Cleft Palate-Craniofacial Journal, 42(5), 565-569.

Rvachew, S., Ohberg, A., Grawburg, M., \& Heyding, J. (2003). Phonological awareness and phonemic perception in 4-year-old children with delayed expressive phonology skills. American Journal of Speech-Language Pathology, 12(4), 463-471.

Scherer, N. J., \& D’antonio, L. L. (1995). Parent questionnaire for screening early language development in children with cleft palate. The Cleft PalateCraniofacial Journal, 32(1), 7-13.

Siegel, L. S. (1993). Phonological processing deficits as the basis of a reading disability. Developmental Review, 13(3), 246-257.

Wagner, R. K., Torgesen, J. K., Rashotte, C. A., Hecht, S. A., Barker, T. A., Burgess, S. R., ..., \& Garon, T. (1997). Changing relations between phonological processing abilities and word-level reading as children develop from beginning to skilled readers: a 5-year longitudinal study. Developmental Psychology, 33(3), 468-479.

Weinfeld, J. P., Johnels, J. Å., \& Persson, C. (2021). Prevalence of reading difficulties in 9-to 10-year old children in Sweden born with cleft palate. The Cleft Palate-Craniofacial Journal, 1-9.

Yang, Y., Yim, D., Kim, S., \& Han, J. (2013). The relationship among receptive vocabulary, non-word repetition, and quick incidental learning in preschoolers with and without delay in vocabulary development. Communication Sciences \& Disorders, 18(4), 379-391. 
Appendix 1. Results of speech-language tests for children with cleft palate in school age.

\begin{tabular}{lclc}
\hline & REVT-R (백분위수) & REVT-E (백분위수) & PCC (백분위수) \\
\hline A & 117점(99\%ile 이상) & 85점(40-50\%ile) & $98.81 \%$ (60-70\%ile) \\
B & 71점(10\%ile 미만) & 83점(30-40\%ile) & $100 \%$ (99\%ile 이상) \\
C & 71점(10\%ile 미만) & 71점(10\%ile 미만) & $97.62 \%(40-50 \%$ ile) \\
D & 87점(60\%ile) & 87점(50-60\%ile) & $90.47 \%$ (10\%ile 미만) \\
E & 63점(10\%ile 미만) & 72점(10\%ile 미만) & $91.67 \%(10 \%$ ile 미만) \\
F & 108점(99\%ile 이상) & 84점(40\%ile) & $95.24 \%(30-40 \%$ ile) \\
G & 96점(80-90\%ile) & 99점(99\%ile 이상) & $88.1 \%(10 \%$ ile 미만) \\
H & 95점(80-90\%ile) & 82점(30-40\%ile) & $96.43 \%(10 \%$ ile 미만) \\
I & 97점(70-80\%ile) & 90점(50\%ile) & $96.43 \%(20-30 \%$ ile) \\
J & 31점(10\%ile 미만) & 54점(10\%ile 미만) & $63.1 \%(10 \%$ ile 미만) \\
\hline
\end{tabular}




\section{국문초록}

\section{초등학교 저학년 구개열 아동의 음운처리 및 읽기 능력}

최유경 1 하승희 ${ }^{2}$

1한림대학교 일반대학원 언어병리청각학과, ${ }^{2}$ 한림대학교 언어청각학부· 청각언어연구소

배경 및 목적: 본 연구는 일반 아동과 학령전기에 말소리장애를 보였던 학령기 구개열 아동 간의 음운처리 능력과 읽기 능력을 각각 비 교하고자 하였다. 방법: 대상자는 초등학교 1,2학년 구개열 아동 10 명(학년 8명, 2 학년 2명)과 일반 아동을 12 명(1학년 8 명, 2 학년 4 명) 으로 구성되었다. 그리고 본 연구에 참여한 구개열 아동들은 모두 학령전기에 말과 언어 발달 문제가 확인되었으며, 언어치료 중재를 권 고받았다. 집단 간 음운인식(음절 및 음소인식), 음운기억(무의미 낱말 따라말하기, 숫자 바로 및 거꾸로 따라말하기), 빠른 자동 이름대 기(숫자 및 글자 빠른 이름대기) 과제를 실시하여 음운처리 하위검사 수행력을 비교하였다. 그리고 해독(자소-음소 일치 낱말 해독, 자 소-음소 불일치 낱말 해독, 의미 낱말 해독, 무의미 낱말 해독), 문단글 읽기 유창성, 읽기이해 과제를 실시하여 읽기 능력을 살펴보았다. 구개열 아동과 일반 아동 집단에서 수용 및 표현 어휘력과 자음정확도, 음운처리 능력과 읽기 능력 간의 상관관계도 살펴보았다. 결과: 먼저 집단 간 음운처리 하위검사수행력을 비교한 결과, 일반 아동보다 구개열 아동이 음절인식과 무의미 낱말 따라말하기 과제에서 유 의하게 낮은 수행력을 보였다. 그리고 집단 간 읽기 하위검사 수행력을 비교하였을 때는 읽기 유창성을 제외한 해독과 읽기이해 과제에 서 모두 구개열 아동이 유의하게 수행력이 낮았다. 구개열 아동의 무의미 음절 따라말하기 수행력은 수용 어휘력과 자음정확도와 매우 높은 상관관계를 보이는 것으로 나타났다. 논의 및 결론: 본 연구는 학령전기에서 말소리장애를 보였던 구개열 아동이 학령기에서도 지속적으로 말-언어 문제를 보일 경우 동시에 음운처리와 읽기 상의 문제를 보인다고 제안한다. 따라서 말소리장애 과거력이 있는 구개 열 아동은 학령전기에서부터 적극적으로 음운처리 능력에 대해 평가해야 한다. 그리고 학령기에 필요한 읽기 능력 향상을 위해 조기 중 재가 필요함을 제안하고 있다.

핵심어: 음운처리 능력, 읽기 능력, 구개열, 학령기

\section{참고문헌}

김미배, 배소영 (2007). 유치원, 초등 2·4 학년의 낱말재인 및 음운인식 능력. 언어치료연구, 16(2), 89-107.

김신영, 손진경, 임동선 (2020). 4-6세 일반아동 및 언어발달지연 아동의 음운인식 및 음운처리 능력이 언어 능력에 미치는 영향. 말소리와 음성과학, 12(1),51-63.

김영태, 홍경훈, 김경희, 장혜성, 이주연 (2009). 수용·표현 어휘력 검사(REVT). 서울: 서울장애인종합복지관.

김애화, 김의정, 황민아; 유현실 (2014). 읽기성취 및 읽기 인지처리 능력검사(Test of Reading Achievement and Reading Cognitive Precesses Ability,

RA-RCP). 서울: 학지사.

박혜원 (2014). 한국 비언어지능검사(K-CTONI-2). 서울: 마인드프레스.

배소영, 김미배, 윤효진, 장승민 (2015). 한국어 읽기 검사(KOLRA). 서울: 학지사.

양윤희, 임동선, 김신영, 한지윤 (2013). 학령 전 어휘발달지체 및 일반 아동의 비단어 따라 말하기, 빠른 우연학습(Quick Incidental Learning)과 수용

어휘와의 관계. Communication Sciences \& Disorders, 18(4), 379-391.

이현정, 김영태, 황보명 (2018). 학령전기 말소리장애 아동의 음운인식능력에 따른 음운처리능력과 언어능력. 언어치료연구, 27(4), 69-77.

피민경, 하승희 (2017). 구개열 아동, 말 늦은 아동, 일반아동의 초기 어휘에 나타난음운 특성. Communication Sciences \& Disorders, 22(2), 328-340.

하승희 (2019). 구개열 아동과 일반아동의 음절성 옹알이의 시작 시기. Communication Sciences \& Disorders, 24(3), 715-723.

하승희 (2020). 말소리장애 유형별 무의미 낱말 따라말하기. Communication Sciences \& Disorders, 25(4), 929-937.

하승희, 김민정, 서동기, 피민경 (2021). 한국 조음음운프로파일(K-APP). 서울: 휴브알앤씨. 
하승희, 정승은, 고경석, 오태석 (2018). 구개성형술 이후 양측 구순구개열 아동의 말 산출 능력. Communication Sciences \& Disorders, 23(4), 982991.

한진순, 심현섭 (2008). 구개열 아동과 일반 아동 및 기능적조음장애 아동의 자음정확도, 말 명료도 및 말 용인도비교. 언어청각장애연구, 13(3), 454476.

\section{ORCID}

최유경(제1저자, 대학원생 https://orcid.org/0000-0002-5798-4800); 하승희(교신저자, 교수 https://orcid.org/0000-0003-2133-3720) 